\title{
Factors associated with utilization of long term family planning methods among women of reproductive age attending Bahir Dar health facilities, Northwest Ethiopia
}

\author{
Endalamaw Tesfa ${ }^{1 *}$ and Hailyesus Gedamu²
}

\begin{abstract}
Objective: This health institution based cross section study was designed to determine factors associated with utilization of long term family planning methods among women reproductive age attending Bahir Dar health facilities.

Result: A total of 406 women were interviewed in this study. The mean age (standard deviation) of the study participants was $26.96 \pm 6.31$. About $99 \%$ of the study participants were consisted from Amhara ethnic group and $60.6 \%$ of them urban dwellers. In this study about $90.9 \%$ of the study participants had information about LTFP methods and $26.4 \%$ of them utilizing the methods. Factors like; knowledge of the women towards LTFP, spousal discussion on FP and occupation of the women affects LTFP utilization ( 6 times, 3 times and 4 times, respectively) when compared with their counter parts. In addition monthly income of the household was also associated to LTFP methods. In this study less percentage (26.4\%) of women's utilizing LTFP methods that were significantly associated with the knowledge of women on LTFP, spousal discussion on FP, occupation of the women and monthly income of the household. As result continuous health education will be recommended.
\end{abstract}

Keywords: Long term family planning, Health facility, Reproductive age women, Bahir Dar

\section{Introduction}

Continuous population growth was become an imperative problem for developing countries [1]. In sub-Saharan Africa like Ethiopia the population growth increases dramatically that adversely affect the socio economic development of the country. As a result, countries are enforced to develop population policy to limit population growth [2]. Family planning (FP) is a tool to control population growth [3]. FP is central to efforts to reduce poverty, promote economic growth, raise female productivity, lower fertility and improve child survival and maternal health. FP can prevent maternal deaths up to $20-35 \%$ [4]. Long term family planning (LTFP) methods had low failure rate, safer and cost effective than short acting

\footnotetext{
*Correspondence: endalamaw2009@gmail.com

1 Department of Biochemistry, College of Medicine and Health Science, Bahir Dar University, P.O. Box 79, Bahir Dar, Ethiopia

Full list of author information is available at the end of the article
}

contraceptives. They prevent pregnancy more than a year in one action without requirement of repeated procedures [5]. Despite its effectiveness, improve maternal health, reduce population growth and reversibility of fertility the acceptance and utilization of LTFP methods were very poor $[6,7]$.

In sub- Sahara Africa utilization LTFP method was very low [8]. According to the Ethiopian demographic health survey (EDHS) mini report in 2014 the prevalence of LTFP method was relatively low [9]. There are several factors that contribute for low prevalence LTFP methods; side effects of the methods, lack of access to the methods, lack of information on the methods, maternal education [10-12]. Monthly income of the household and residence are determinants of LTFP methods [13, 14]. This study was designed to assess the factors associated to utilization of LTFP methods among women reproductive age attending Bahir Dar health facilities, Northwest Ethiopia. 


\section{Main text \\ Methods \\ Study design, study population and sampling}

Health institution based cross-sectional study was conducted at Bahir Dar town health facilities from May to June, 2017. The town had two governmental hospitals and ten health centers that provide FP services. All reproductive age (15-49) women users of FP method coming to Bahir Dar town health facilities were our source population. All reproductive age women obtaining FP methods or FP counseling service during the study period were our study population. Utilization of LTFP method was a dependent variable. Socio-demographic variables, obstetric variables and other clinical variables were considered as an independent variable. LTFP operationally defined as contraceptive methods that delay pregnancy for 1 year and above (implants and intrauterine contraceptive devices).

A simple random sampling technique was applied to get the study participants. The sample size was estimated by using single proportion formula. The total sample size was 406 . The calculated sample was allocated into four governmental health facilities (Han, Shimbit, Zenzelma health centers and Addis Alem hospital) the detail sampling procedure attached as Additional file 1 .

\section{Data collection and analysis}

Data was collected after we obtained informed verbal consent from each participant by using interviewer administered structured questionnaire. The questionnaire was prepared in English then translated into Amharic later retranslated into English. Four BSc midwives and two BSc nurses were selected for data collection and supervision, respectively. Training was given for data collectors and supervisors to maintain data quality. Before the actual data collection pre-test were conducted in Durebete Health Center. Based on the pretest result, questionnaires were revised. Data were analyzed by using SPSS version 20 software. Descriptive statistics, binary and multiple logistic regressions was computed. Those variables were significant at $P$-value $\leq 0.2$ were entered into multivariate analysis. The odds ratio was calculated to assess the association and strength of association of variables. P-value $<0.05$ was taken as a cut point.

\section{Ethical consideration}

Ethical clearance was obtained from Bahir Dar University, College of Medicine and Health Sciences ethical review committee. Permission was also requested from the administrators of four health institutions. We precede our data collection after we obtained verbal informed consent from each study participants.

\section{Results}

\section{Socio-demographic characteristics}

A total of 406 individuals included in this study. The mean age (standard deviation) of the study participant was $26.96 \pm 6.31$. In this study almost all (99\%) of the study participants were consisted from an Amhara ethnic group. Majority of the study participants were a follower of Orthodox Christian religion (85.5) and lived in the urban area $(60.6 \%)$. Most of them were married $(81.5 \%)$. The mean age of marriage and first delivery was $18.82 \pm 2.45$ and $20.86 \pm 2.87$, respectively (Table 1 ).

\section{Reproductive characteristics of LTFP utilization}

Almost all (99.5\%) of the study participants had knowledge about modern FP methods and $90.9 \%$ of the women had information about LTFP methods. About 64.5\% of the study participants were pregnant of this $51.3 \%$ of them were become pregnant two and $<$ two times. In this study the major reason of women not utilizing LTFP method were fear of side effect, lack of information and need of more children accounts $66.9 \%, 12.4 \%$ and $5.4 \%$, respectively (Table 2).

\section{Factors affecting LTFP utilization}

Thirteen independent variables were analyzed in logistic regression to know their association. Variables which were significant at $\mathrm{P} \leq 0.2$ entered into multivariate logistic regressions. Out of thirteen variables four were significantly associated with LTFP methods. These are knowledge to LTFP, spousal discussion on FP methods, occupation and monthly income. Those participants who were merchants in occupation had 4 times more likely to use LTFP than others. Women who have knowledge on LTFP were about 6 times more likely to practice LTFP methods than women who don't have knowledge. Women who discussed about LTFP methods with their partners had 3 times more likely to utilize LTFP than their counterparts (Table 3 ).

\section{Discussion}

In this study the overall utilization of LTFP methods among reproductive age women was $26.4 \%$. The finding of this research was almost similar in studies conducted in Mbarara district and Areka town $[11,15]$. The prevalence of this research result was slightly higher than in studies conducted in different parts of Ethiopia [16-21]. This higher prevalence might be due to the accessibility of health facilities, increased awareness of the community due to health extension workers and the study design. 
Table 1 Socio- demographic characteristics of women attending Bahir Dar health facilities, Northwest Ethiopia, 2017

\begin{tabular}{|c|c|c|c|}
\hline Variables & Response & Frequency & Percentage \\
\hline \multirow[t]{4}{*}{ Age (years) } & $15-19$ & 71 & 17.5 \\
\hline & $20-24$ & 145 & 35.7 \\
\hline & $25-29$ & 109 & 26.8 \\
\hline & $\geq 30$ & 81 & 20.0 \\
\hline \multirow[t]{4}{*}{ Marital status } & Single & 56 & 13.8 \\
\hline & Married & 331 & 81.5 \\
\hline & Divorced & 4 & 1.0 \\
\hline & Widowed & 15 & 3.7 \\
\hline \multirow[t]{2}{*}{ Residences } & Urban & 246 & 60.6 \\
\hline & Rural & 160 & 39.4 \\
\hline \multirow[t]{3}{*}{ Religion } & Orthodox Christian & 348 & 85.7 \\
\hline & Muslim & 53 & 13.1 \\
\hline & Other & 5 & 1.2 \\
\hline \multirow[t]{2}{*}{ Ethnicity } & Amhara & 402 & 99.0 \\
\hline & Other & 4 & 1.0 \\
\hline \multirow[t]{4}{*}{ Educational status } & No formal education & 111 & 27.3 \\
\hline & Primary education & 149 & 36.7 \\
\hline & Secondary education & 74 & 18.3 \\
\hline & College and university & 72 & 17.7 \\
\hline \multirow[t]{2}{*}{ Availability of health facility at a distances of $5 \mathrm{~km}$} & Yes & 305 & 75.1 \\
\hline & No & 101 & 24.9 \\
\hline \multirow[t]{5}{*}{ Occupation } & Government employed & 76 & 18.7 \\
\hline & Housewife & 144 & 35.5 \\
\hline & Merchant & 90 & 22.2 \\
\hline & Student & 56 & 13.8 \\
\hline & Other & 40 & 9.8 \\
\hline \multirow[t]{5}{*}{ Monthly income in Ethiopian Birr } & $<1000$ & 44 & 10.8 \\
\hline & $1001-2000$ & 50 & 12.3 \\
\hline & $2001-3500$ & 112 & 27.6 \\
\hline & $3501-5000$ & 72 & 17.7 \\
\hline & $>5000$ & 128 & 31.5 \\
\hline
\end{tabular}

In this study almost all $99.5 \%$ of study participant have information about modern contraceptive methods and $90.9 \%$ of the study participant had information on LTFP methods. This is in line with 2014 Ethiopian Demographic Health survey mini report (96.5\%). The prevalence of mothers that use any modern contraceptive methods and LTFP methods in this study was $91.4 \%$ and $26.4 \%$, respectively [9]. This result lower than studies conducted in Kampala and Ethiopia [7, 12, 17, 22]. In this study factors like; knowledge of women towards LTFP method, habit of partner discussion, less than 1000 Ethiopian birr monthly income and become merchant by occupation of the women were found to be determinants of LTFP methods.

This study revealed that women who discussed with their husband about LTFP methods were three times more likely to use LTFP methods than their counter parts. This is supported by studies conducted in Uganda, Rwanda and Ethiopia [1, 4, 8, 16, 20, 22, 23]. Out of the variables which showed significant associations at the multi-variable logistic regression analysis, high odds of using LTFP methods were seen among women with knowledge of LTFP methods. This finding suggests that women with knowledge of LTFP methods are more likely to practice FP services than their counter parts. This finding was strengthened by other studies conducted in Ethiopia [1, 2, 7, 19, 23, 24]. In this study, merchants by occupation more likely to utilized LTFP methods than their counter parts. Occupation of the women was associated to FP utilization in different studies conducted in Ethiopia [15, 25-27]. Monthly income of the household was positively associated with LTFP utilization. However, 
Table 2 Reproductive characteristics of women attending Bahir Dar health facilities, Northwest Ethiopia, 2017

\begin{tabular}{|c|c|c|c|}
\hline Variables & Response & Frequency & Percent \\
\hline \multirow[t]{2}{*}{ Knowledge on contraceptive } & Yes & 404 & 99.5 \\
\hline & No & 2 & 0.5 \\
\hline \multirow[t]{2}{*}{ Utilization of contraceptive } & Yes & 371 & 91.5 \\
\hline & No & 35 & 8.6 \\
\hline \multirow[t]{5}{*}{ Choice of methods } & Injectable & 225 & 55.4 \\
\hline & Implant & 103 & 25.4 \\
\hline & Oral contraceptive & 34 & 8.4 \\
\hline & Emergency & 5 & 1.2 \\
\hline & IUCD & 4 & 1.0 \\
\hline \multirow[t]{2}{*}{ Knowledge on LTFP methods } & Yes & 369 & 90.9 \\
\hline & No & 37 & 9.1 \\
\hline \multirow[t]{2}{*}{ LTFP utilization } & Yes & 107 & 26.4 \\
\hline & No & 299 & 73.6 \\
\hline \multirow[t]{2}{*}{ History of pregnancy } & Yes & 261 & 64.5 \\
\hline & No & 145 & 35.7 \\
\hline \multirow[t]{2}{*}{ Gravidity } & $\leq 2$ Pregnancies & 134 & 51.3 \\
\hline & $>2$ Pregnancies & 127 & 48.7 \\
\hline \multirow[t]{2}{*}{ Parity } & $\leq 2$ Alive children & 131 & 54.1 \\
\hline & > 2 Alive children & 111 & 45.9 \\
\hline \multirow[t]{2}{*}{ Desire of more children } & Yes & 210 & 51.7 \\
\hline & No & 196 & 48.3 \\
\hline \multirow[t]{2}{*}{ Purpose of FP utilization } & For spacing & 304 & 74.9 \\
\hline & For limiting & 102 & 25.1 \\
\hline \multirow[t]{2}{*}{ History of abortion } & Yes & 57 & 14.0 \\
\hline & No & 349 & 86.0 \\
\hline \multirow[t]{2}{*}{ Spousal discussion on FP methods } & Yes & 324 & 79.8 \\
\hline & No & 82 & 20.2 \\
\hline \multirow[t]{2}{*}{ Accessibility of FP methods } & Yes & 392 & 96.6 \\
\hline & No & 14 & 3.4 \\
\hline \multirow{2}{*}{$\begin{array}{l}\text { Birth interval between children (if they have } \geq 2 \text { children) } \\
\text { (years) }\end{array}$} & $\leq 2$ & 5 & 2.7 \\
\hline & $>2$ & 178 & 97.3 \\
\hline \multirow[t]{4}{*}{ Reason not taking LTFP methods } & Lack of information & 37 & 12.4 \\
\hline & Fear of side effect & 200 & 66.9 \\
\hline & Need of more children & 16 & 5.4 \\
\hline & Other & 46 & 15.4 \\
\hline
\end{tabular}

LTFP long term family planning, FP family planning, IUCD intrauterine contraceptive device

after adjustment it doesn't show significant association. This is supported by studies conducted in Ethiopia [21].

In this study knowledge of LTFP was relatively high (90.9\%). However, its utilization was low (26.4\%). This is due to factors like; knowledge of women to LTFP methods, habit of partner discussion, monthly income of the household and becoming merchant by occupation were found to be determinants of LTFP utilization. As a result, improving the norms of partner discussion and continuous health education will be encouraged. In addition to explore factors in detail another longitudinal study will be recommend.

\section{Limitations of the study}

This study isn't free from limitation. Its limitation relies on the method part; health institution based cross sectional study doesn't much explore the determinants about LTFP methods like community based and longitudinal studies. As a result another longitudinal study will be necessary to explore determinants in detail. Numbers related to knowledge of FP methods might be relatively higher to give an inference to general population. 
Table 3 Logistic regression analysis of women attending Bahir Dar health facilities, Northwest Ethiopia, 2017

\begin{tabular}{|c|c|c|c|c|c|c|}
\hline \multirow[t]{2}{*}{ Variables } & \multirow[t]{2}{*}{ Response } & \multicolumn{2}{|c|}{ Utilization of LTFP } & \multirow[t]{2}{*}{ COR at $95 \% \mathrm{Cl}$} & \multirow[t]{2}{*}{ Sig } & \multirow[t]{2}{*}{ AOR at $95 \% \mathrm{Cl}$} \\
\hline & & Yes & Total & & & \\
\hline \multirow[t]{4}{*}{ Age of the respondent (years) } & $15-19$ & 12 & 71 & $2.070(0.946,4.528)$ & 0.068 & $0.945(0.401,2.231)$ \\
\hline & $20-24$ & 32 & 145 & $1.487(0.802,2.757)$ & 0.208 & $0.526(0.197,1.405)$ \\
\hline & $25-29$ & 39 & 109 & $0.756(0.408,1.401)$ & 0.374 & $0.534(0.178,1.604)$ \\
\hline & $\geq 30$ & 24 & 81 & 1 & 1 & 1 \\
\hline \multirow[t]{3}{*}{ Marital status } & Single & 8 & 56 & 1 & 1 & 1 \\
\hline & Married & 97 & 331 & $0.402(0.183,0.881)$ & 0.023 & $0.394(0.061,2.556)$ \\
\hline & Others & 2 & 19 & $1.417(0.273,7.342)$ & 0.678 & $0.415(0.078,2.208)$ \\
\hline \multirow[t]{2}{*}{ Residence } & Urban & 69 & 246 & $0.799(0.505,1.263)$ & 0.337 & $1.581(0.815,3.067)$ \\
\hline & Rural & 38 & 160 & 1 & 1 & 1 \\
\hline \multirow[t]{4}{*}{ Educational status } & No formal educated & 21 & 111 & 1 & 1 & 1 \\
\hline & Primary education & 43 & 149 & $0.789(0.400,1.557)$ & 0.494 & $0.787(0.263,2.357)$ \\
\hline & Secondary education & 14 & 74 & $1.000(0.472,2.119)$ & 1.000 & $1.188(0.422,3.339)$ \\
\hline & College and university & 29 & 72 & $0.346(0.177,0.675)$ & 0.002 & $2.245(0.832,6.058)$ \\
\hline \multirow[t]{5}{*}{ Occupation } & Government employed & 33 & 81 & $0.301(0.112,0.805)$ & 0.017 & $1.798(0.678,4.770)$ \\
\hline & Merchant & 23 & 89 & $0.594(0.219,1.612)$ & $0.306^{* *}$ & $3.873(1.155,12.986)$ \\
\hline & Student & 6 & 57 & $1.759(0.519,5.956)$ & 0.364 & $1.509(0.552,4.122)$ \\
\hline & Housewife & 39 & 144 & $0.557(0.215,1.444)$ & 0.229 & $1.772(0.460,6.823)$ \\
\hline & Other & 6 & 35 & 1 & 1 & 1 \\
\hline \multirow[t]{2}{*}{ Availability of health facility at $5 \mathrm{~km}$} & Yes & 83 & 305 & $0.834(0.494,1.406)$ & 0.495 & $0.988(0.425,2.296)$ \\
\hline & No & 24 & 101 & 1 & 1 & 1 \\
\hline \multirow[t]{5}{*}{ Monthly income in Ethiopian Birr } & $<1000$ & 6 & 44 & $1.855(0.714,4.823)$ & $0.205^{* *}$ & $0.319(0.104,0.977)$ \\
\hline & $1001-2000$ & 20 & 50 & $0.439(0.218,0.886)$ & 0.021 & $0.754(0.249,2.284)$ \\
\hline & $2001-3500$ & 29 & 112 & $0.838(0.464,1.515)$ & 0.559 & $0.676(0.208,2.201)$ \\
\hline & $3501-5000$ & 23 & 72 & $0.624(0.327,1.190)$ & 0.152 & $1.047(0.337,3.249)$ \\
\hline & $>5000$ & 29 & 128 & 1 & 1 & 1 \\
\hline \multirow[t]{2}{*}{ Knowledge of LTFP Methods } & Yes & 105 & 369 & $0.144(0.034,0.608)$ & $0.008^{* *}$ & $6.250(1.326,29.472)$ \\
\hline & No & 2 & 37 & 1 & 1 & 1 \\
\hline \multirow[t]{2}{*}{ Spousal discussion on FP } & Yes & 98 & 324 & $3.517(1.692,7.312)$ & $0.001^{* *}$ & $2.398(1.021,5.633)$ \\
\hline & No & 9 & 82 & 1 & 1 & 1 \\
\hline \multirow[t]{2}{*}{ Desire of more children } & Yes & 62 & 210 & 1 & 1 & 1 \\
\hline & No & 45 & 196 & $1.406(0.900,2.195)$ & 0.134 & $0.937(0.539,1.627)$ \\
\hline \multirow[t]{2}{*}{ History of pregnancy } & Yes & 81 & 261 & $0.486(0.295,0.800)$ & 0.005 & $1.294(0.607,2.758)$ \\
\hline & No & 26 & 145 & 1 & 1 & 1 \\
\hline \multirow[t]{2}{*}{ History of abortion } & Yes & 14 & 57 & $1.116(0.584,2.133)$ & 0.740 & $0.896(0.416,1.932)$ \\
\hline & No & 93 & 349 & 1 & 1 & 1 \\
\hline \multirow[t]{2}{*}{ Accessibility of FP methods } & Yes & 103 & 392 & $1.122(0.344,3.657)$ & 0.848 & $0.344(0.076,1.549)$ \\
\hline & No & 4 & 14 & 1 & 1 & 1 \\
\hline
\end{tabular}

** Shows statistical significant association in the adjusted odds ratio

\section{Additional file}

Additional file 1: Figure S1. Schematic presentation on sampling procedure of factors associated with utilization of long term family planning methods among women of reproductive age attending Bahir Dar health facilities, Northwest Ethiopia, 2017. Figure S2. Bar graph of prevalence of family planning utilization among reproductive age women in Bahir Dar town, Northwest Ethiopia, 2017.

\section{Abbreviations}

FP: family planning; LTFP: long term family planning; IUCD: intrauterine contraceptive devices; $\mathrm{Cl}$ : confidence interval; COR: crude odds ratio; AOR: adjusted odds ratio; $\mathrm{HC}$ : health center.

\section{Authors' contributions}

ET Involved in method development, data collection tool development, data analysis, write up of the manuscript and $\mathrm{HG}$ also participated in method and data collection tool development, data analysis, write up of the manuscript. Both authors read and approved the final manuscript. 


\author{
Author details \\ ${ }^{1}$ Department of Biochemistry, College of Medicine and Health Science, Bahir \\ Dar University, P.O. Box 79, Bahir Dar, Ethiopia. ${ }^{2}$ Department of Nursing, Col- \\ lege of Medicine and Health Science, Bahir Dar University, P.O. Box 79, Bahir \\ Dar, Ethiopia.
}

\section{Acknowledgements}

The authors want to acknowledge the management of the four health facilities. In addition we wish to thank the data collectors and study participants for their valuable time.

\section{Competing interests}

The authors declare that they have no competing interests.

\section{Availability of data materials}

All relevant data are included within the manuscript. If it is necessary it is possible to contact the corresponding author to get additional material.

\section{Consent of publication}

Not applicable.

\section{Ethics approval and consent to participate}

Ethical clearance was obtained from Bahir Dar University, College of Medicine and Health Sciences ethical review committee. Permission was also requested from the administrators of four health institutions. We precede our data collection after we obtained verbal informed consent from each study participants. Even though our study population includes reproductive age women between 15 and 49 years unfortunately there were no study participants under 16 years. So, we haven't imposed to parent or guardian permission.

\section{Funding}

There is no funding organization.

\section{Publisher's Note}

Springer Nature remains neutral with regard to jurisdictional claims in published maps and institutional affiliations.

Received: 14 November 2018 Accepted: 19 December 2018 Published online: 27 December 2018

\section{References}

1. Earsido A, Gebeyehu A, Kisi T. Determinants of long acting and permanent contraceptive methods utilization among married women in Hossana Town, Southern Ethiopia: a case-control study. J Pregnancy Child Health. 2015;2(3):1000165.

2. Belayneh F, Abreha S, Meskele M. Knowledge, attitude and factors associated with the use of long acting and permanent contraceptive methods among women of reproductive age in Gesuba Town, Southern Ethiopia. J Biol Agric Healthcare. 2015;5(21):14.

3. Mekonnen W, Worku A. Determinants of low family planning use and high unmet need in Butajira District, South Central Ethiopia. Reprod Health. 2011;8:37

4. Wudie S, Tegabu D, Asmamaw T, Dejenu G. Factors affecting the use of long-acting reversible contraceptive methods among married women in Debre Markos Town, Northwest Ethiopia. Gynecol Obstet. 2014:14(5). Online ISSN: 2249-4618 \& Print ISSN: 0975-5888.

5. Shimeka A, Asmamaw A. Determinants of long acting contraceptive use among reproductive age women in Ethiopia: evidence from EDHS 2011. Sci J Public Health. 2015:3(1):143-9.

6. Gebremichael H, Haile F, Dessie A, Birhane A, Alemayehu M, Yebyo H. Acceptance of long acting contraceptive methods and associated factors among women in Mekelle city, Northern Ethiopia. Sci J Public Health. 2014;2(4):349-55.

7. Baye C, Adefris M, Kindie M, Assefa Y. Factors associated with utilization of long-acting and permanent contraceptive methods among women who have decided not to have more children in Gondar city. BMC Women's Health. 2017;17:75. https://doi.org/10.1186/s12905-017-0432-9.

8. Bikorimana E. Barriers to the use of long acting contraceptive methods among married women of reproductive age in Kicukiro District, Rwanda. Int J Sci Res Publ. 2015;5(12):513-21.

9. Central Statistical Agency. Ethiopian demographic health survey mini report. Ethiopia: Central Statistical Agency; 2014. p. 32-9.

10. Atnafe $M$, Assefa N, Alemayehu T. Long-acting family planning method switching among revisit clients of public health facilities in Dire Dawa, Ethiopia. Contracept Reprod Med. 2016;1:18. https://doi.org/10.1186/ s40834-016-0028-z.

11. Tibaijuka L, Odongo R, Welikhe E, Mukisa W, Kugonza L, Busingye I. Factors influencing use of long-acting versus short-acting contraceptive methods among reproductive-age women in a resource-limited setting in Mbarara district, Uganda. BMC Women's Health. 2017;17:25.

12. Ewnetu Y, Gebre E, Damte M. Determinants of long acting reversible contraception method use among mothers in extended postpartum period, Durame Town, Southern Ethiopia: a cross sectional community based survey. Health. 2015;7:1315-26. https://doi.org/10.4236/healt h.2015.710146.

13. Azmoude E, Behnam H, Barati-Far S, Aradmehr M. Factors affecting the use of long-acting and permanent contraceptive methods among married women of reproductive age in East of Iran. Women's Health Bull. 2017:4(3):1-8

14. Tsehaye W, Mengistu D, Berhe K. Assessment of modern contraceptive methods utilization and its determinant factors among women of reproductive age groups at Shire Endaslasie Town, Tigray, Northern Ethiopia. J Bio Innov. 2014;3(3):144-69.

15. Yohannis M. Utilization of reversible long acting family planning methods among married 15-49 years women in Areka town, Southern Ethiopia. Int J Sci Rep. 2016;2(1):1-6.

16. Adbaru S, Megabiaw B, Shimeka A. Demand for long acting contraceptive methods and associated factors among family planning service users, North west Ethiopia: a health facility based cross sectional study. BMC Res Notes. 2015:8:29.

17. Gulte T, Hailu D, Workineh Y. Predictors of long acting contraceptives utilization among reproductive age women in Arba Minch Zuria district, Ethiopia. Qual Prim Care. 2016;24(1):17-22.

18. Adera A, Fantahun A, Gebrekirstos K, Gebregziabher W, Gebru W, Woldemicheal Y. Assessment of factors affecting long acting of family planning utilization in Adigrat Town, Tigray, North-East Ethiopia. Am J Health Res. 2015;3(4):239-47.

19. Alemayehu M, Belachew T, Tilahun T. Factors associated with utilization of long acting and permanent contraceptive methods among married women of reproductive age in Mekelle town, Tigray region, north Ethiopia. BMC Pregnancy Childbirth. 2012;12:6.

20. Sahilemichael A, Temesgen K, Gemechukejela A. Determinants of long acting reversible contraceptives use among child bearing age women in Dendi District, Western Ethiopia. J Women's Health Care. 2015;4(242):1-4.

21. Mohammed A, Woldeyohannes D, Feleke A, Megabiaw B. Determinants of modern contraceptive utilization among married women of reproductive age group in North Shoa Zone, Amhara Region, Ethiopia. Reprod Health. 2014;11:13.

22. Anguzu R, Tweheyo R, Sekandi J, Zalwango V. Knowledge and attitudes towards use of long acting reversible contraceptives among women of reproductive age in Lubaga division, Kampala district. Uganda. BMC Res Notes. 2014:7:153.

23. Birhan T, Degu G, Birhanu Z. Assessment of modern contraceptive practice and associated factors among currently married women age 15-49 years in Farta District, South Gondar Zone, North West Ethiopia. Sci J Public Health. 2014;2(6):507-12.

24. Mekonnen G, Enquselassie F, Tesfaye G, Semahegn A. Prevalence and factors affecting use of long acting and permanent contraceptive methods in Jinka town, Southern Ethiopia: a cross sectional study. Pan Afr Med J. 2014. https://doi.org/10.11604/pamj.2014.18.98.3421.

25. Fekadu H, Kumera A, Yesuf EA, Hussien G, Tafa M. Prevalence and determinant factors of long acting contraceptive utilization among married women of reproductive age in Adaba Town, West Arsi Zone, Oromia, 
Ethiopia. J Women's Health Care. 2017. https://doi.org/10.4172/21670420.1000360.

26. Sufa A, Tekelab T, Wirtu D. Determinants of long acting and permanent contraceptive methods utilization among married women of reproductive age groups in western Ethiopia: a cross-sectional study. Pan Afr Med J. 2015;1:1. https://doi.org/10.11604/pamj.2015.21.246.5835.
27. Abdisa B, Mideksa L. Factors associated with utilization of long acting and permanent contraceptive methods among women of reproductive age group in Jigjiga Town. Int Hum Anat Physiol. 2017;7(2):6.
Ready to submit your research? Choose BMC and benefit from:

- fast, convenient online submission

- thorough peer review by experienced researchers in your field

- rapid publication on acceptance

- support for research data, including large and complex data types

- gold Open Access which fosters wider collaboration and increased citations

- maximum visibility for your research: over $100 \mathrm{M}$ website views per year

At BMC, research is always in progress.

Learn more biomedcentral.com/submissions 